\title{
Prototipe Sistem Kendali Suhu dan Kelembaban Kandang Ayam Broiler melalui Blynk Server berbasis Android
}

\author{
Fitri Puspasari ${ }^{1}$, Imam Fahrurrozi ${ }^{1}$, Trias Prima Satya ${ }^{1}$, Galih Setyawan ${ }^{1}$, \\ Muhammad Rifqi Al Fauzan ${ }^{1}$ \\ ${ }^{1}$ Departemen Teknik Elektro dan Informatika Sekolah Vokasi, \\ Universitas Gadjah Mada, Yogyakarta, Indonesia
}

* Penulis Penanggungjawab.E-mail: fitri.puspasari@ugm.ac.id (Fitri Puspasari)

\begin{abstract}
ABSTRAK
Ayam broiler merupakan hewan ternak yang memiliki ciri khas pertumbuhan yang cepat dan pertumbuhannya dipengaruhi oleh suhu lingkungan. Kandang merupakan salah satu bagian dari manajemen ternak ayam broiler yang sangat penting untuk diperhatikan, terutama mengenai suhu dan kelembaban. Tujuan penelitian ini adalah membuat prototipe sistem pengukuran besaran fisis berupa pengaturan dan pengukuran suhu dan kelembaban secara otomatis pada kandang ayam broiler berbasis android untuk memudahkan monitoring. Pada penelitian ini sensor yang digunakan untuk mengukur suhu dan kelembaban dalam sistem monitoring ini adalah sensor DHT11, sedangkan sebagai pengendalinya digunakan Arduino Due. Ketika sensor DHT11 membaca data, maka Arduino akan merekam dan memproses data tersebut. Data pengukuran dapat disimpan dalam bentuk database yang dapat ditampilkan pada halaman aplikasi Blynk berbasis android.
\end{abstract}

Kata Kunci : Suhu; Kelembaban; DHT11; Arduino due; Android. 


\begin{abstract}
Broiler chickens are livestock that have a characteristic that is fast growth and its growth is influenced by the temperature of the environment. Cage is one part of the management of broiler chickens which is very important, especially regarding temperature and humidity. The purpose of this study was to make a prototype of the physical measurement system in the form of setting and measuring temperature and humidity automatically in an Android-based broiler chicken coop to facilitate monitoring. In this study the sensors used to measure temperature and humidity in the monitoring system are DHT11 sensors, while Arduino Due is used as the controller. When the DHT11 sensor read the data, the Arduino will record and process the data. Measurement data can be stored in the form of a database that can be displayed on Blynk app based on Android.
\end{abstract}

Keywords: Temperature; Humidity; DHT11; Arduino due; Android

\section{Pendahuluan}

Permasalahan tingginya suhu lingkungan dapat mengakibatkan ayam mengalamai stres dikarenakan ayam tergolong dalam hewan berdarah panas yang tidak mempunyai kelenjar keringat serta hampir seluruh tubuhnya tertutup bulu. Kondisi seperti ini mengakibatkan ternak unggas dalam kondisi panas mengalami kesulitan untuk membuang panas tubuhnya ke lingkungan. Hal tersebut berdampak pada produktivitas dan bahkan dapat berujung pada kematian.

Berdasarkan latar belakang di atas, diperlukan suatu perangkat yang berfungsi untuk memantau tingkat suhu ,kelembaban di dalam kandang ayam broiler. Sistem dalam prototipe ini diharapkan dapat memberikan solusi bagi peternak dalam mengurangi kematian dan kerugian dalam produktivitas ayam ternak broiler.

Pada penelitian ini, sensor suhu dan kelembaban yang digunakan adalah tipe DHT11 (Gambar 1.) dengan keluaran dalam bentuk sinyal digital. Sensor DHT11 ini memiliki pengaturan suhu dan kelembaban yang terkalibrasi dan memiliki kestabilan jangka panjang [1].

Sensor DHT 11 memiliki range pengukuran suhu $0^{\circ}$ sampai $50^{\circ}$, dan 20 - $90 \%$ RH (Relative Humidity) untuk pengukuran kelembaban, dengan akurasi pengukuran suhu $\pm 2^{\circ} \mathrm{C}$ dan $\pm 5 \% \mathrm{RH}$ pada pengukuran kelembaban [2]. 


\section{Gambar 1. Sensor DHT11}

Pemrograman dan bagian perangkat keras sensor suhu dan kelembaban berinteraksi dengan arduino Due. Arduino DUE adalah papan mikrokontroler yang terdiri dari compiler bahasa pemograman standar dan sebuah boot loader yang dieksekusi dalam microkontroller. Platform elektronik ini memiliki 54 pin input / output digital, 12 input analog, 4 UART, 84 MHz clock, koneksi USB OTG yang mampu, 2 DAC, 2 TWI, colokan listrik, header SPI, header JTAG, tombol reset dan tombol hapus [3].

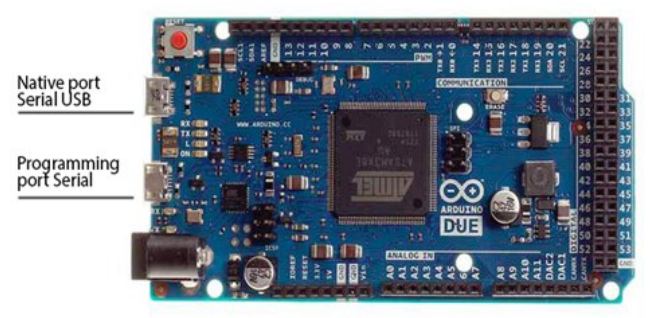

Gambar 2. Arduino Due microcontroller board [4]

Selain sensor, pada sistem perangkat keras ini juga terdapat modul ESP8266 yang merupakan chip yang di dalamnya sudah termasuk prosesor dan memori sebagai Transceiver untuk melakukan koneksi pada jaringan wifi. Modul ini mentransmisikan hasil bacaan sensor yang telah diolah arduino Due dikirimkan ke platform IoT thingsboard [5].

Platform IoT yang digunakan untuk mengendalikan dan memantau sistem kerja hardware yang telah terhubung ke android adalah aplikasi Blynk (Gambar 3.) Aplikasi ini sangat membantu dalam sistem telemetri, antara lain pengontrolan jarak jauh, menampilkan data dari masing-masing sensor yang terhubung, menyimpan data, memberi tanda/notifikasi, dan lain-lain [6].

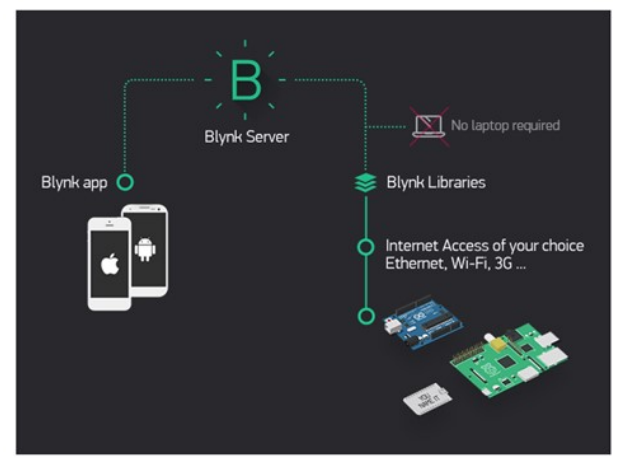

Gambar 3. Komponen utama platform [6]

\section{Bahan dan Metode}

Secara umum prototype sistem telemetri dalam penelitian ini terbagi menjadi 2 bagian : hardware dan software. Gambar 4 menunjukkan bagian pertama yaitu arsitektur hardware yang menunjukkan sensor yang dikontrol oleh Arduino dan hasil pengukuran akan diakses menggunakan modul gsm atau router yang dipasang di kandang ayam broiler. 


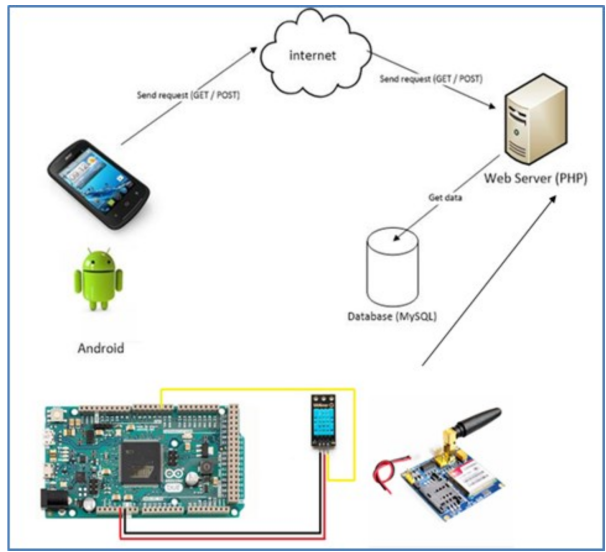

Gambar 4. Arsitektur Hardware

Pada bagian kedua yaitu software, melibatkan sistem telemetri yang dapat diakses melalui android dengan menggunakan server Blynk. Data ini juga merupakan data realtime dari sensor -sensor yang ada pada kandang broiler. Diagram alir tahapan penelitian seperti pada Gambar 5.

\section{Hasil dan Pembahasan}

Hasil pengukuran sensor selama pengujian di kandang ayam broiler menunjukkan sedikit perbedaan antara sensor satu dengan yang lain. Hal tersebut dikarenakan penempatan sensor suhu dan kelembaban satu dengan yang lain kami beri jarak 15 meter (dengan total panjang kandang ayam broiler 85 meter). Gambar 6 adalah data hasil uji coba pemrosesan data berbasis arduino, sebelum dihubungkan ke server aplikasi Blynk.

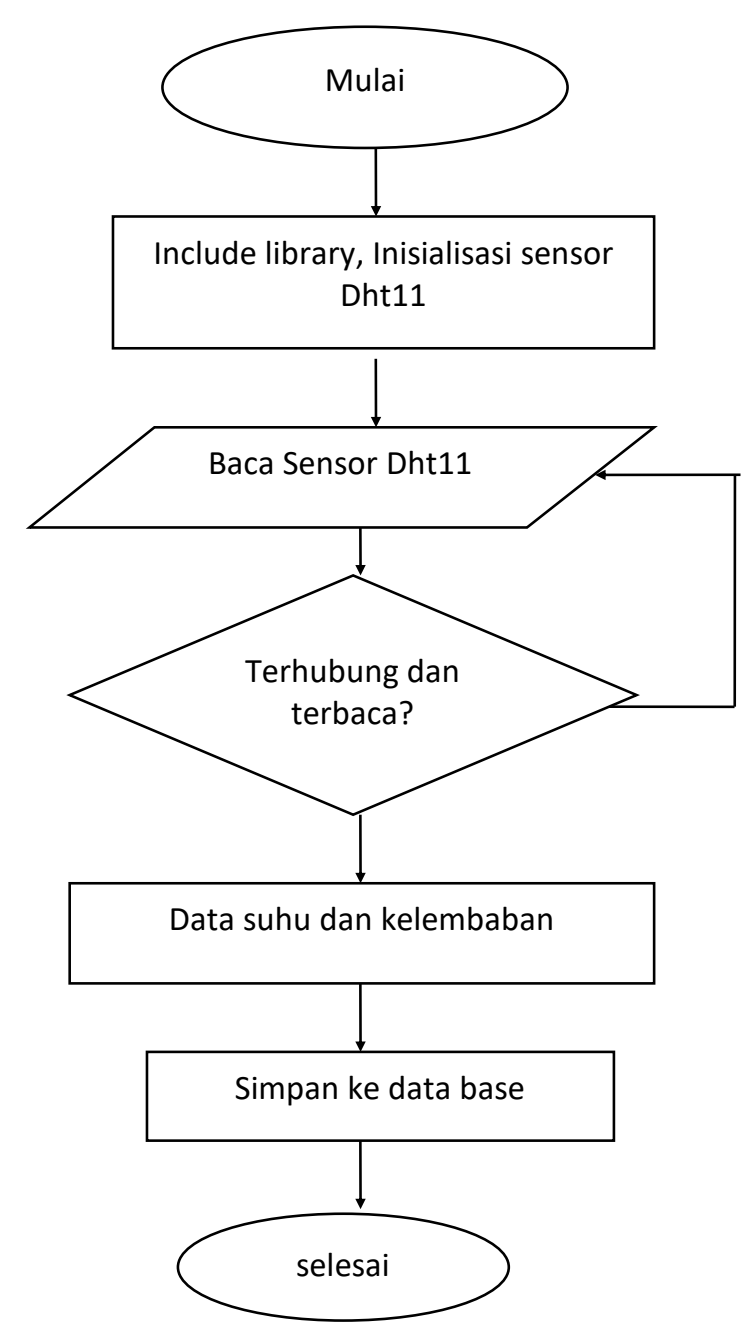

Gambar 5. Tahapan Penelitian

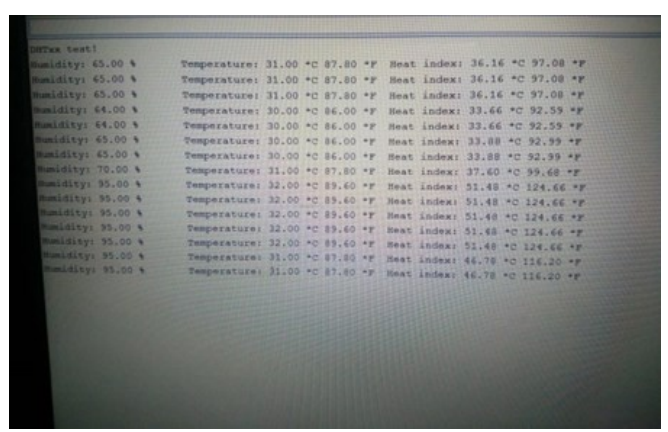

Gambar 6. Pemrosesan Data 
Setiap sensor mengirim data yang ditangkap oleh prototype sistem telemetri (android). Hasil data suhu melalui aplikasi Blynk dapat dilihat pada Gambar 6. Suhu di kandang ayam broiler menunjukkan data rata-rata $33,4^{\circ}$ celcius. Sedangkan hasil data sensor kelembaban menunjukkan rata-rata 67,6 RH (Relative Humidity).

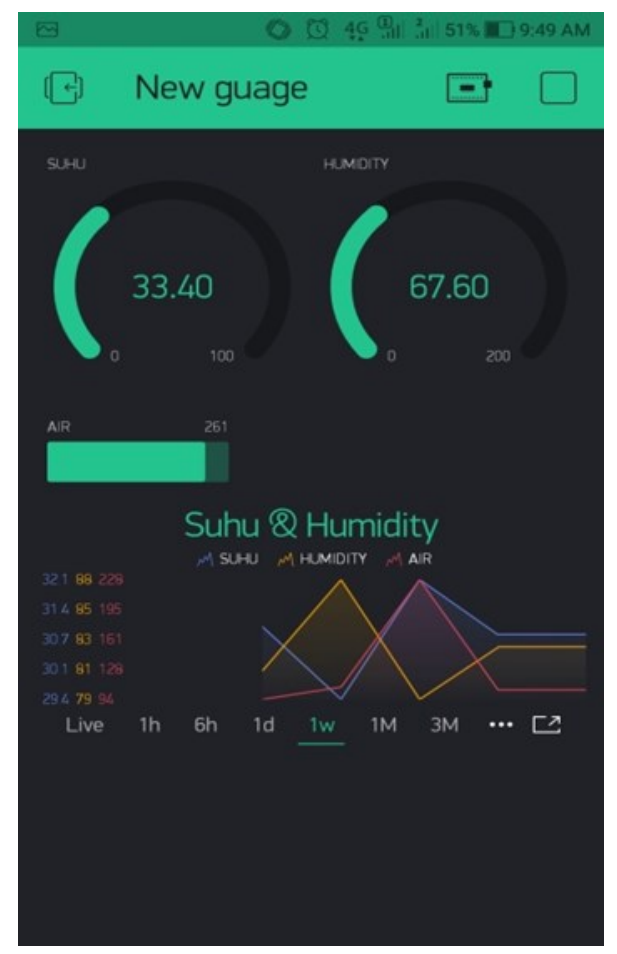

Gambar 7. Tampilan Prototipe Sistem

\section{Simpulan}

Berdasarkan penelitian dan pembahasan yang telah dilakukan, diperoleh kesimpulan bahwa telah berhasil dibuat prototype sistem telemetri pengukuran besaran suhu dan kelembaban kandang ayam broiler melalui aplikasi Blynk berbasis android.

\section{Ucapan Terima Kasih}

Terima Kasih kepada pihak Sekolah Vokasi UGM yang telah membantu dalam pendanaan penelitian ini.

\section{Referensi}

1. DFRobot. , 2012, DHT11 Temperature and Humidity Sensor (SKU: DFR0067), http:// www.dfrobot.com/wiki/index.php/ DHT11_Temperature and_Humidit y_Sensor_(SKU:_DFR0067). $\leftarrow$ Website

2. https://www.mouser.com/ds/2/758/ DHT11-Technical-Data-SheetTranslated-Version-1143054.pdf. $\leftarrow$ Website

3. L. Bitjoka, M. Ndje, A. T. Boum, J. Song-Manguelle (2017). Implementation of quadratic dynamic matrix control on arduino due ARM cortex -M3 microcontroller board, Journal of Engineering Technology, 6 (2),682-695. Journal

4. http://www.farnell.com/ datasheets/1682211.pdf $\leftarrow$ Website

5. S.Sunitha (2017). Distance Measurement using Ultrasonic Sensor and NodeMCU, International Research Journal of Engineering and Technology, 4(6), 1794-1797. $\leftarrow$ Journal

6. https://docs.blynk.cc/ $\leftarrow$ Website 